\title{
Hubungan Tingkat Pengetahuan PasienTuberculosis (TB) Dengan Kepatuhan Minum Obat di Puskesmas Gunung Sari
}

\author{
Nur Radiah ${ }^{1 *}$, Tony Fernan Diansa ${ }^{1}$, dan Lale Syifaun Nufus ${ }^{1}$ \\ ${ }^{1}$ Jurusan Ilmu Farmasi, Universitas Nahdlatul wathan, Mataram, Indonesia \\ *Email : nurradiah90@yahoo.com
}

\begin{abstract}
Abstrak : Di puskesmas Gunungsari, prevelensi penyakit Tuberculosis cukup tinggi. Dimana Tuberculosis menempati posisi kedua tertinggi dalam sepuluh penyakit terbanyak. Tujuan dari penelitian ini adalah untuk mengetahui apakah ada hubungan antara tingkat pengetahuan pasien tuberculosis dengan kepatuhan minum obat di puskesmas gunungsari. Metode penelitian yang digunakan adalah metode deskriptif, dan crossectional study yaitu data yang menyangkut variabel dependen dan independen akan dikumpulkan secara bersamaan. Populasi dalam penelitian ini sebanyak 192 pasien dengan sampel yang didapatkan sebanyak 130 pasien, dan teknik pengambilan sampel yang digunakan adalah porpusive sampling. Hasil penelitian diketahui bahwa pengetahuan pasien tentang Tuberculosis sebagian besar kategori kurang dengan frekuensi 52 orang (40\%) dan kepatuhan minum obat sebagian besar kategori tidak patuh dengan frekuensi 71 orang $(54,6 \%)$. Analisis data yang digunakan adalah uji chi square, Hasil uji statistik yang didapatkan adalah Nilai Signifikansi $=0,000(>0,05)$ yang berarti Ha diterima yang berarti bahwa terdapat hubungan yang signifikan antara tingkat pengetahuan dengan kepatuhan minum obat pasien hipertensi peserta Prolanis di Puskesmas Gunungsari.
\end{abstract}

Kata Kunci : Tuberculosis (TB), Tingkat Pengetahuan, Kepatuhan Minum Obat

\section{Pendahuluan}

Di Indonesia menunjukkan bahwa lingkungan sangat dominan mempengaruhi kejadian TB, baru - baru ini penelitian di Yogyakarta bahwa lingkungan fisik perumahan berhubungan dengan kejadian $\mathrm{TB}$, besarnya permasalahan Kesehatan masyarakat akibat TB sehingga WHO memberikan ultimatum dengan peringatan global, dalam kesepakatan yang bertujuan membebaskan dunia dari TB pada tahun 2050 (Anonim, 2017). Penyakit tuberculosis merupakan penyakit menular yang bisa menyerang otak, tulang belakang, kelenjar getah bening, paru - paru dan oragan - organ lainnya. Namun pada kebanyakan kasus, TB ini lebih sering menyerang paru - paru. Resiko terinfeksi TB ini semakin tinggi terutama pada kebiasaan mengkonsumsi alcohol dan menetap dilingkungan yang kotor. Adapun bahaya dari penyakit ini jika pasien kurang dalam pengetahuan tentang TB, tidak mendapatkan penanganan terapi yang tepat atau pasien tidak patuh dalam mengkonsumsi obat, hal ini dapat meyebabkan bakteri tersebut akan resistensi (Anonim, 2018). Pasien di puskesmas gunung sari masih memiliki tingkat pengetahuan yang relatif rendah tentang penyakit tuberculosis dan pentingnya kepatuhan dalam mengkonsumsi obat anti tuberculosis, sehingga perlu dilakukan penelitian terkait masalah tersebut.

\section{Metode Penelitian}

Desain Penelitian Menggunakan metode deskriptif dengan pendekatan Cross Sectional study adalah suatu metode yang bertujuan untuk membuat deskriptif, gambaran atau lukisan sistematis, factual dan akurat mengenai tingkat pengetahuan pasien dan kepatuhan minum obat tuberculosis di Puskesmas Gunung Sari.

Populasi Populasi dalam penelitian ini adalah semua pasien tuberculosis yang tercatat di puskesmas Gunung Sari sejumlah 192 orang pasien.

Sampel Sampel penelitian sebanyak 130 pasien dengan tehnik pengambilan sampel yang digunakan adalah purposive sampling yang memenuhi kriteria inklusi.

\section{Hasil dan Pembahasan}

3.1 Karakteristik Responden berdasarkan umur pasien

\begin{tabular}{|c|c|c|c|}
\hline No & Umur & $\begin{array}{c}\text { Jumlah } \\
\text { Responden }\end{array}$ & $\begin{array}{c}\text { Presentase } \\
(\boldsymbol{\%})\end{array}$ \\
\hline 1 & $15-20$ tahun & 56 & $43 \%$ \\
\hline 2 & $21-30$ tahun & 30 & $23 \%$ \\
\hline 3 & $31-40$ tahun & 20 & $15 \%$ \\
\hline 4 & $41-59$ tahun & 24 & $19 \%$ \\
\hline \multicolumn{2}{|c|}{ Total } & $\mathbf{1 3 0}$ & $\mathbf{1 0 0 \%}$ \\
\hline
\end{tabular}


Berdasarkan tabel di atas dapat diketahui bahwa umur responden sebagian besar adalah 1520 tahun dengan frekuensi sebanyak 56 pasien (43\%), pada pasien umur 21-30 tahun sebanyak 30 orang $(23 \%)$, pada pasien umur $31-40$ tahun sebanyak 20 orang $(15 \%)$, dan pada pasien umur 41-59 tahun sebanyak 24 orang (19\%). Hal ini dapat di lihat bahwa pasien TB yang terbanyak adalah umur $>15$ tahun yaitu termasuk umur produktif. Sehingga semakin rendah umur seseorang maka semakin besar resiko untuk menderita TB paru.

\subsection{Karakteristik Responden Berdasarkan Jenis Kelamin}

\begin{tabular}{|c|c|c|c|}
\hline No & $\begin{array}{c}\text { Jenis } \\
\text { kelamin }\end{array}$ & $\begin{array}{c}\text { Jumlah } \\
\text { Responden }\end{array}$ & $\begin{array}{c}\text { Presentase } \\
(\mathbf{\%})\end{array}$ \\
\hline 1 & Laki-laki & 50 & $38,5 \%$ \\
\hline 2 & Perempuan & 80 & $61,5 \%$ \\
\hline \multicolumn{2}{|c|}{ Total } & $\mathbf{1 3 0}$ & $\mathbf{1 0 0 \%}$ \\
\hline
\end{tabular}

Berdasarkan tabel di atas dapat diketahui bahwa jenis kelamin pasien terbanyak adalah perempuan yaitu 80 pasien $(61,5 \%)$, sedangkan pada responden laki-laki sebanyak 50 pasien $(38,5 \%)$. Hal ini dikarenakan bahwa pasien perempuan memiliki resiko lebih besar pada penurunan imunitas tubuh dan pengaruh kadar hormone estrogen sehingga sangat rentan tertular bakteri tuberculosis (Dotulong 2015).

\subsection{Tingkat Pengetahuan Responden Tentang Tuberculosis (TB)}

\begin{tabular}{|c|c|c|c|}
\hline No & Pengetahuan & $\begin{array}{c}\text { Jumlah } \\
\text { Responden }\end{array}$ & $\begin{array}{c}\text { Presentase } \\
(\mathbf{\%})\end{array}$ \\
\hline 1 & Baik (76\%-100\%) & 41 & $31,5 \%$ \\
\hline 2 & Cukup (56\%-75\%) & 37 & $28,5 \%$ \\
\hline 3 & Kurang ( 0\%-55\%) & 52 & $40 \%$ \\
\hline \multicolumn{2}{|c|}{ Total } & $\mathbf{1 3 0}$ & $\mathbf{1 0 0 \%}$ \\
\hline
\end{tabular}

Berdasarkan tabel di atas dapat diketahui bahwa responden yang memiliki tingkat pengetahuan yang baik tentang tuberculosis adalah 41 orang $(31,5 \%)$, yang memiliki tingkat pengetahuan tentang tuberculosis cukup adalah 37 orang $(28,5 \%)$ dan yang memiliki tingkat pengetahuan tentang tuberculosis kurang adalah 52 orang $(40 \%)$. Hal ini dikarenakan kurangnya sumber informasi yang didapat oleh pasien dari tenaga farmasi dan media massa seperti koran, televisi ataupun radio dan juga dari puskesmas terdekat yang memberikan penyuluhan tentang penyakit tuberculosis.Tenaga kesehatan (farmasis) harus berkerjasama dengan masyarakat dalam rangka meningkatkan upaya edukatif pada masyarakat yang masih memiliki pemahaman bahwa penyakit tuberculosis paru bukan merupakan penyakit kutukan atau ghaib, serta kurangnya pengetahun masyarakat terkait sumber penularan penyakit tuberculosis

\subsection{Kepatuhan Minum Obat Pasien Tuberculosis (TB)}

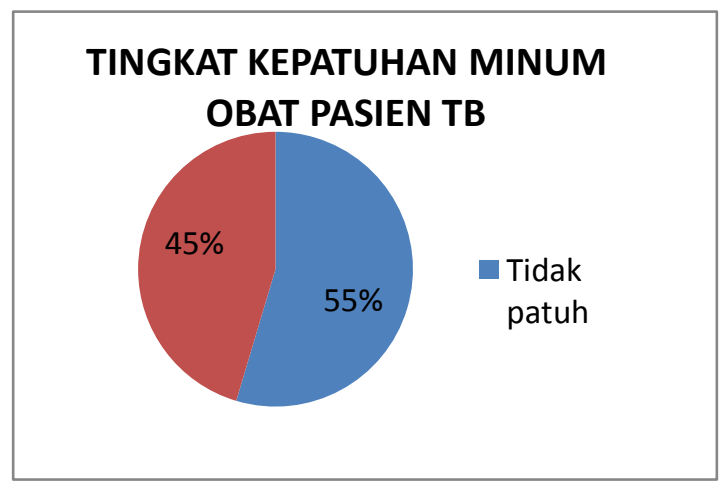

\section{Gambar 1. Grafik Tingkat Kepatuhan Minum Obat Pasien Tuberculosis (TB)}

Berdasarkan gambar 1 dapat diketahui bahwa pasien yang patuh dalam minum obat tuberculosis adalah 59 orang $(45,4 \%)$ dan pasien yang tidak patuh adalah 71 orang (54,6\%). Penyebab ketidakpatuhan dari 71 pasien tersebut ialah ketidakkepatuhan dalam melakukan kontrol ulang pada pasien tuberculosis di Puskesmas Gunungsari karena pasien tidak merasakan adannya keluhan lagi, pasien melakukan pengobatan alternatif, pada saat melakukan perjalanan atau meninggalkan rumah, tidak membawa obat tuberculosis dan ketika merasa tubuh mulai membaik, tidak meneruskan meminum obat sampai habis. 
3.5 Tabel Hubungan tingkat Pengetahuan Pasien Tuberculosis (TB) dengan Kepatuhan Minum Obat Di Puskesmas Gunungsari.

\begin{tabular}{|c|c|c|c|c|c|c|c|c|}
\hline \multirow[b]{2}{*}{ No } & \multirow[b]{2}{*}{ Pengetahuan } & \multicolumn{4}{|c|}{ Kepatuhan obat } & \multirow[b]{2}{*}{ Jumlah } & \multirow[t]{2}{*}{$\%$} & \multirow[b]{2}{*}{ Sig. } \\
\hline & & Patuh & $\%$ & $\begin{array}{l}\text { Tidak } \\
\text { patuh }\end{array}$ & $\%$ & & & \\
\hline 1 & Baik & 32 & 24.6 & 9 & 6.9 & 41 & 31,5 & \multirow{4}{*}{0,000} \\
\hline 2 & Cukup & 15 & 11.6 & 22 & 16.9 & 37 & 28,5 & \\
\hline 3 & Kurang & 12 & 9.2 & 40 & 30.8 & 52 & 40 & \\
\hline & Total & 59 & 45.4 & 71 & 54.6 & 130 & 100 & \\
\hline
\end{tabular}

Berdasarkan Tabel di atas diatas dapat diketahui bahwa Hasil uji statistik yang telah dilakukan, didapatkan Nilai Signifikansi $=0,000<$ 0,05 yang berarti bahwa terdapat hubungan yang signifikan antara tingkat pengetahuan pasien dengan kepatuhan minum obat pasien Tuberculosis di Puskesmas Gunungsari. Hal ini dikarenakan adanya upaya yang telah dilakukan oleh petugas kesehatan (tenaga farmasi) diantaranya dengan mensosialisasikan pentingnya menjalani pengobatan yang teratur bagi pasien tuberculosis, penyuluhan kesehatan mengenai penyakit tuberculosis, pemberian brosur tentang penyakit tuberculosis. Dan secara tidak langsung mampu meningkatkan pengetahuan pasien tuberculosis. Pengetahuan yang kurang mengenai kepatuhan minum obat dapat menurunkan kesadaran terhadap pentingnya minum obat akibatnya dapat terjadi komplikasi berlanjut. Kepatuhan minum obat antituberculosis dapat dicapai apabila pasien patuh minum obat yang diberikan secara teratur atau konsisten.

\section{Kesimpulan}

1. Berdasarkan identifikasi tingkat pengetahuan pasien tentang tuberculosis, sebagian besar adalah kategori baik tentang tuberculosis adalah 41 orang $(31,5 \%)$ yang memiliki tingkat pengetahuan tentang tuberculosis cukup adalah 37 orang $(28,5 \%)$ dan yang memiliki tingkat pengetahuan tentang tuberculosis kurang adalah 52 orang $(40 \%)$.

2. Berdasarkan identifikasi kepatuhan minum obat pasien tentang tuberculosis, sebagian besar adalah kategori patuh dengan frekuensi 59 orang $(45,4 \%)$ dan responden yang tidak patuh adalah 71 orang $(54,6 \%)$.

\section{Daftar Pustaka}

Anonim.2017, Pemberantasan dan Penanggulangan Tuberculosis.Yogyakarta Anonim. 2009. Mikrobakterium Tuberculosis. Jurnal Kedokteran

Anonim. 2018. Analisis faktor Risiko Kejadia Penyakit Tuberkulosis bagi Masyarakat Daerah Kumuh Kota Palembang. Jurnal Kesehatan Lingkungan Indonesia
Anonim. 2007. Pedoman Diagnosis dan Penatalaksaan Tuberculosis di Indonesia, available, http : //www.klik.pdpi.com / consensus $/ \mathrm{TB} / \mathrm{tb} / \mathrm{html}$. Diakses tanggal 14 september 2019

Budiman dan Rianto, 2013.Kuesioner Pengetahuan dan Sikap Dalam Penelitian Kesehatan. Jakarta. Salemba Medika

Chandra B. 2012. Pengantar kesehatan Lingkungan, Jakarta : EGC

Djojodibroto, D. 2009, Respirologi (Respiratory Medicine). Jakarta : EGC Kementerian Kesehatan RI. 2015, Tuberculosis, Temukan Obat Sampai Sembuh. Jakarta Kemenkes RI

Leban, Yoanes. 2008. Penyakit TBC dan Cara Pencegahannya.Penyakit Paru (BP4) Minggiran. Yogyakarta

Nuraini, B. (2015). Risk factors of hypertension. 4, $10-19$

Prabowo, D., 2012 hubungan tingkat pengatahuan tentang tuberculosis dengan kepatuhan minum obat pada penderita TBm paru di BBKM Surakarta (Doctoral dissertation, Universitas Muhammadiyah Surakarta)

Notoadmodjo, Soekidjo. ( 2014). Metedologi Penelitian Kesehatan, Jakarta, Rineka Cipta.

Padila. (2012). Buku Ajar: Keperawatan keluarga. Yogyakarta: Nuha Medik 